ISA

Arboriculture \& Urban Forestry 2015. 41(2): 88-102

\title{
Evaluation of General-Use Insecticides for Preventing Host Colonization by New Jersey Southern Pine Beetles
}

\author{
B.L. Strom, W.K. Oldland, J.R. Meeker, and J. Dunn
}

\begin{abstract}
Four general-use insecticides (Astro ${ }^{\oplus}$, Onyx ${ }^{\oplus}$, Dominion ${ }^{\circledR}$ Tree \& Shrub, and Xytect $2 \mathrm{~F}^{\oplus}$ ) were evaluated for their effectiveness at preventing attacks by the southern pine beetle (SPB) (Dendroctonus frontalis) and the small southern pine engraver (Ips avulsus) using a previously developed small-bolt method. Evaluations were conducted between 58 and 126 days post treatment. Southern pine beetles from New Jersey and Mississippi, U.S., were evaluated using a mixture of field and laboratory small-bolt trials; beetle origin did not appear to affect results. Astro and Onyx bole sprays were effective at reducing or eliminating attack by SPB, while the imidacloprid soil drench products (Dominion and Xytect) were ineffective. With I. avulsus in Louisiana, U.S., Astro was effective at reducing bole utilization at 58 and 83 days posttreatment but failed at 126 days. Onyx, Dominion, and Xytect were ineffective against $I$. avulsus in these tests. Imidacloprid phloem residues averaged 0.74 ( $\mu \mathrm{g} / \mathrm{g}$ phloem dry weight) for Dominion and 1.31 for Xytect, values that are similar to other studies but low for purposes of control. These results support previous findings that systemic imidacloprid is ineffective for protecting pines against Dendroctonus bark beetles and that bole sprays with bifenthrin or permethrin can be effective. However, permethrin was the only active ingredient that was effective against $I$. avulsus in the current study.

Key Words. Bifenthrin; Dendroctonus frontalis; Imidacloprid; Insecticide; Ips avulsus; Mississippi; New Jersey; Permethrin; Pinus; Soil Drench; Southern Pine Beetle; Southern Pine Engraver; Systemic Insecticide.
\end{abstract}

The southern pine beetle (SPB) (Dendroctonus frontalis) was first observed in the state of New Jersey, U.S., in this century in 2001 (Klischies and Battersby 2002). Prior to this, the most recent outbreak in southern New Jersey is believed to have been in 1939 (The Philadelphia Inquirer 2011). Populations of this aggressive beetle have been killing an increasing number of pines in southern New Jersey for the past six years, with especially widespread host mortality being observed since 2010 . The beetle has been identified in survey traps as far north as Monmouth County, but pine mortality has been observed predominantly south of the Mullica River, which forms most of the northern border of Atlantic County (Figure 1). Six counties have experienced tree mortality caused by SPB: Atlantic, Cape May, Cumberland, Camden, Gloucester, and Salem; the first of these three being most impacted (Figure 1). Pines have been killed on more than 12,950 ha during the current outbreak, with about 10,926.5 ha killed since 2010 (Ferguson et al. 2013).
The primary SPB host in New Jersey is pitch pine (Pinus rigida). Pitch pine is the most common pine in the state and is a predominant forest tree, comprising about $15 \%$ of living forestland trees and $34 \%$ of all trees (Crocker 2012). The species accounts for the majority of observed mortality from SPB, but beetle preferences among pitch pine and the other hosts in New Jersey, including shortleaf pine (P. echi$n a t a)$, loblolly pine (P. taeda), Virginia pine ( $P$. virginiana), eastern white pine (P. strobus), and red pine (P. resinosa) (Klischies and Battersby 2002), have not been determined. Southern pine beetle kills trees wherever hosts are found. In southern New Jersey, pitch pine is a common tree in urban and suburban forests, which generally have areas that are overstocked and over-aged, providing ample hosts for SPB to be a pest (Cameron 1987; Hayes et al. 1996).

Typical of eastern states in the U.S., the majority of forests in New Jersey are privately owned with an average holding size of 4.9 ha (Crocker et al. 2008). Most forest owners in the state consider aesthetics a 
primary ownership objective, but the vast majority do not have management plans (Crocker et al. 2008). Recreation is also a primary use for New Jersey forests under all ownership types. These statistics suggest high-value individual pines and groups of pines will continue to be threatened by SPB in New Jersey and that private, nonindustrial landowners will consider prevention activities in a high-value, urban setting. This context puts a focus on managing individual trees and includes insecticidal treatments as both a central option for direct control, and especially for protection of selected trees from attack. This is in contrast to a general forest context in which mitigation of overall damage is the primary consideration and in which tree felling is the central management activity. In this study, the primary research objective was to evaluate general-use insecticides, a term applied to products that are not on the restricted use list for New Jersey (New Jersey Government 2013), for the prevention of SPB attacks on pine hosts. Because the SPB outbreak is ongoing, researchers endeavored to generate test results with labeled products as quickly as possible, so that homeowners and practitioners may be informed. Methods and treatments were chosen with this objective in mind; more extensive evaluations of these and other tree protection products in situ may also be of interest.

Systemic products and bole sprays are registered by US-EPA for preventive applications against conifer-infesting bark beetles (Coleoptera: Curculionidae: Scolytinae). In various formulations, the active ingredients (AIs) bifenthrin, carbaryl, and permethrin are labeled for prophylactic application as bole sprays against bark beetles. Carbaryl is ineffective against SPB (Berisford et al. 1981; Zhong et al. 1994; Strom and Roton 2009) and was excluded from these tests. Bifenthrin and permethrin exist in general-use formulations for New Jersey (Onyx ${ }^{\oplus}$ and Astro $^{\oplus}$, respectively, along with generic products), although other products based on these same AIs (e.g., Onyx $\operatorname{Pro}^{\oplus}$ ) are considered restricted use and are only available to licensed applicators. The study authors are aware of at least six AIs that are registered for systemic application against tree pests (acephate, avermectin, bidrin, imidacloprid, emamectin benzoate, dinotefuran), but the majority of them have been ineffective against bark beetles (Haverty et al. 1996; DeGomez et al. 2006; Grosman and Upton

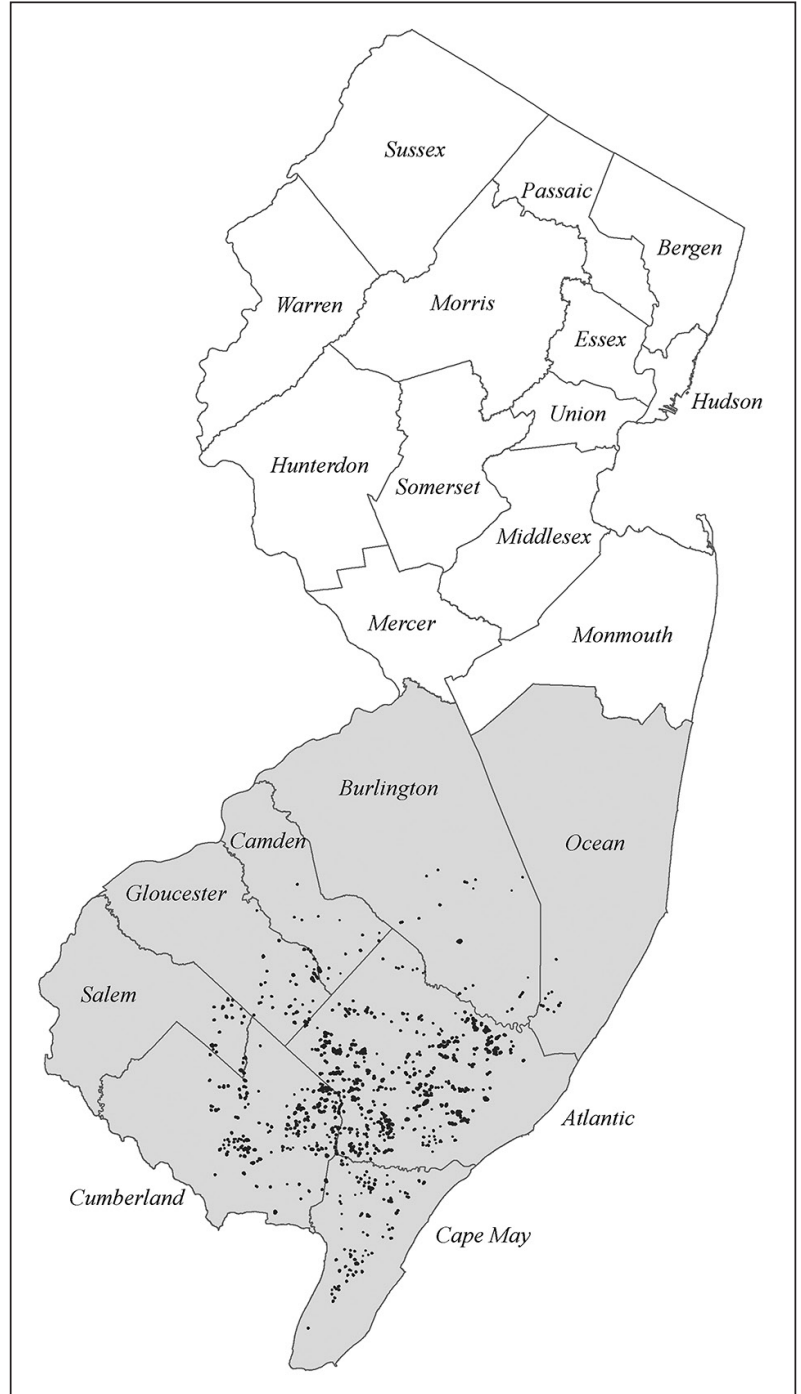

Figure 1. Map of counties comprising New Jersey, U.S. The shaded area are those with known SPB infestations; markers show 2012 infestations. Populations of the southern pine beetle have been in outbreak status in New Jersey since 2010.

2006; Grosman et al. 2010). The most promising of these AIs for bark beetles is emamectin benzoate (TREE-age ${ }^{\oplus}$; Syngenta Crop Protection, Greensboro, North Carolina, U.S.); however, evaluations with this product against bark beetles continue, and it is a restricted-use product in its current formulation, which leaves primarily the neonicotinoids imidacloprid (e.g., Xytect $2 \mathrm{~F}^{\oplus}$, Dominion ${ }^{\oplus}$ Tree \& Shrub) and dinotefuran (Safari ${ }^{\circledR}$ ) as meeting the criteria. Neither imidacloprid nor dinotefuran products have been effective in previous studies against pine-infesting bark beetles (DeGomez et al. 2006; Grosman and Upton 2006), and the Safari label only lists mountain pine beetle (D. ponderosae). 
However, the uncertainty of achieving successful application (i.e., sufficient movement to phloem), particularly by soil drench, along with the ready availability and lower cost of imidacloprid products (relative to Safari), led researchers to include imidacloprid in this evaluation, but not dinotefuran. The wide availability of these products and their ease of application make them an obvious choice by do-it-yourself homeowners for use against SPB.

As mentioned, the primary objective of this study was to assess the effects of general-use insecticides prophylactically applied to pine hosts against New Jersey SPB. Four products were evaluated using a series of small-bolt trials (Strom and Roton 2009; Strom and Roton 2011): Onyx (23.4\% bifenthrin; FMC Corp., Philadelphia, Pennsylvania, U.S.), Astro (36.8\% permethrin; FMC Corp., Philadelphia, Pennsylvania, U.S.), Martin's Dominion Tree \& Shrub (hereafter Dominion; $1.47 \%$ imidacloprid, Control Solutions, Inc., Pasadena, Texas, U.S.), and Xytect 2F (hereafter Xytect; 21.4\% imidacloprid; Rainbow Treecare Scientific Advancements, Minnetonka, Minnesota, U.S.). All are labeled for application against bark beetles and none was considered restricted use in New Jersey at the time of the study. Dominion is a generic product, similar to Bayer Advanced $^{\text {tw }}$ Tree \& Shrub, while Xytect was of interest because its label allowed an application rate of twice as much AI. Both were applied as soil drenches, while Onyx and Astro were applied as bole sprays. With facilities and staff in Louisiana, U.S., and previously developed methods for such research, the study authors addressed research objectives by treating trees in central Louisiana and challenging them with SPB from New Jersey and Mississippi, U.S. Researchers also challenged treatments with Ips avulsus, because this species provides reliable pressures in areas of Louisiana, and to extend results to this typically less severe but oftentimes more present pest of pines.

\section{MATERIALS AND METHODS}

\section{Application of Tree Protection Treatments}

Thirty loblolly pines (average $\mathrm{DBH}=11.4 \mathrm{~cm}$ ) were selected in central Louisiana for this study. Each tree received one of five randomly assigned treatments: untreated control, Astro, Onyx, Dominion, or Xytect. Treatments were applied on March 14, 2012, using the maximum label rate of each product. This resulted in an average per tree application rate of $12 \mathrm{ml}(\sim 2.6 \mathrm{ml} \mathrm{AI}) / 2.5$ $\mathrm{cm} \mathrm{DBH}$ for Xytect, and $90.3 \mathrm{ml}(\sim 1.3 \mathrm{ml} \mathrm{AI}) /$ $2.5 \mathrm{~cm} \mathrm{DBH}$ for Dominion. For consistency of application between products in the experimental design, researchers adjusted label instructions for treatment with imidacloprid products. Application of soil drenches was made in $3.79 \mathrm{~L}$ of tap water to each tree and maximum label rates were used (per DBH $\mathrm{cm}$ ) regardless of tree $\mathrm{DBH}$. Raking around the base of each tree provided a mineral soil surface and a raised barrier of litter detritus to help eliminate product movement from the target area. Bole sprays were applied to a maximum height of $2.5 \mathrm{~m}$ using a handheld garden sprayer (Ace Hardware model number 7215064). Label rates for bark beetles were followed for Onyx (2 pt / 100 gal) and Astro (5.35 qt / 100 gal), providing a mixed product with $0.06 \%$ AI (bifenthrin) for Onyx and $0.5 \%$ AI (permethrin) for Astro. Imidacloprid product labels suggest a 60 -day minimum waiting period following soil drench applications to allow product uptake, so treatment time was selected to allow challenge by SPB beginning mid to late May 2012. At the appropriate time, trees were felled and bucked into small bolts (10-12 cm long) to allow products to be challenged by SPB in field and laboratory trials (Strom and Roton 2009; Strom and Roton 2011). Companion bolts from each tree were stripped of their phloem for determination of imidacloprid residue concentrations (Fischer et al. 2009).

In 2011, similar trials in New Jersey were attempted but did not result in sufficient attacks of control bolts for a valid test of treatment effectiveness (Table 1). However, imidacloprid residue concentrations were determined from tree phloem tissue and are reported herein. Loblolly pines were treated on May 26, 2011, using application methods similar to 2012. In addition, drought conditions in 2011 forced researchers to apply $3.7 \mathrm{~L}$ of water per tree at one and five days after soil drench application. Trees were felled, bucked, and the phloem removed for residues on July 29, 2011 (64 days posttreatment) and August 24, 2011 (90 days posttreatment). 
Table 1. Descriptions of individual experimental trials conducted as part of this study with the southern pine beetle (SPB) or Ips avulsus (IPs). Insecticide residue concentrations were determined from phloem collected from each untreated and imidacloprid-treated study tree after felling.

\begin{tabular}{|c|c|c|c|c|c|c|}
\hline Evaluation & Site & $\begin{array}{l}\text { Insect species } \\
\text { source }\end{array}$ & Dates of trial & Trial set ${ }^{z}$ & Days posttreatment ${ }^{y}$ & Valid test ${ }^{x}$ \\
\hline NJ Field 11-1 & Glassboro & SPB-NJ feral & Aug 3-10 2011 & 4 & 69 & $\mathrm{~N}$ \\
\hline NJ Field 11-2 & Winslow & SPB-NJ feral & Aug 30-Sept 8, 2011 & 5 & 96 & $\mathrm{~N}$ \\
\hline NJ Field 1 & Clarks & SPB-NJ feral & May $15-19,2012$ & 1 & 62 & $\mathrm{~N}$ \\
\hline NJ Field 2 & Harding & SPB-NJ feral & May 15-20, 2012 & 1 & 62 & $\mathrm{Y}$ \\
\hline MS Field 3 & Homochitto & SPB-MS feral & June 5-12, 2012 & 2 & 83 & $\mathrm{Y}$ \\
\hline NJ Lab 1 & Laboratory & SPB-NJ bolts ${ }^{w}$ & May 25-27, 2012 & 2 & 72 & $\mathrm{Y}$ \\
\hline NJ Lab 2 & Laboratory & SPB-NJ bolts ${ }^{w}$ & May 31-June 2, 2012 & 2 & 78 & $\mathrm{Y}$ \\
\hline MS Lab 3 & Laboratory & SPB-MS bolts ${ }^{v}$ & July 16-18, 2012 & 3 & 124 & $\mathrm{Y}$ \\
\hline LA Field 1 & Stuart & Ips-LA feral & May 14-21, 2012 & 1 & 61 & $\mathrm{Y}$ \\
\hline LA Field 2 & Stuart & Ips-LA feral & June 5-12, 2012 & 2 & 83 & $\mathrm{Y}$ \\
\hline LA Field 3 & Stuart & Ips-LA feral & July $18-25,2012$ & 3 & 126 & $\mathrm{Y}$ \\
\hline
\end{tabular}

${ }^{\mathrm{z}} 1$ = cut on May 11, 2012; 2 = cut on May 25, 2012; 3 = cut on July 15, 2012; 4 = cut on July 29, 2011; 5 = cut on August 24, 2011.

${ }^{y}$ At first day of bolt's exposure to beetles.

${ }^{\mathrm{x}}$ Based on attack number (SPB) or proportion of subsamples with activity (Ips avulsus) observed on control/untreated bolts.

${ }^{\text {w }}$ Infested pitch pine from Harding site.

${ }^{v}$ Infested loblolly pine from Homochitto National Forest.

Note: $\mathrm{NJ}=$ New Jersey; MS = Mississippi; LA = Louisiana.

\section{Small-Bolt Field Evaluation of Tree Protection Treatments}

For the New Jersey (NJ) field portion of the study, two sites on state property were selected based upon adequate beetle activity and stand accessibility. Stands at both sites were predominantly pitch pine, one being mostly sawtimber with a closed canopy (Clarks Landing) and the other being sapling-sized pitch pines and a more open canopy (Harding). Both sites had active SPB populations as indicated by freshly attacked trees.

Treated trees in Louisiana were cut and bucked into small bolts on May 11, 2012 (58 days posttreatment), and deployed in traps at the NJ sites from May 15 to 20, 2012 (Table 1; Figure 2). The evaluation method was adapted from similar experiments conducted with Ips bark beetles in central Louisiana (Strom and Roton 2011). A single cut bolt $(\sim 11 \mathrm{~cm}$ $\times 11 \mathrm{~cm})$ was placed into a bucket that replaced the usual collecting cup on a Lindgren multiplefunnel trap (12-funnel; Synergy Semiochemicals Corp., Burnaby, British Columbia, Canada) (Lindgren 1983; Figure 2) and held the bolt in place. Two attractants were hung at the middle funnel of each trap, frontalin (racemic, $600 \mathrm{mg}$ load; release rate of $5.9 \mathrm{mg}$ / day at $23.1^{\circ} \mathrm{C}$ ) and an Ultra High Release pouch with SPB monoterpene blend (70\% alphapinene [75\%-(+) enantiomere], 30\% beta-pinene; release rate of $3.7 \mathrm{~g} /$ day at $26.8^{\circ} \mathrm{C}$ ) (USDA Forest Service 2010). A third attractant, endo-brevicomin (release rate of $0.4 \mathrm{mg} /$ day at $20^{\circ} \mathrm{C}$ ), was attached to vegetation approximately $4 \mathrm{~m}$ horizontal dis- tance from each trap. This is the most attractive, commercially available lure combination for SPB in the southeastern U.S. (Sullivan et al. 2007), and was so selected to provide the greatest challenge to treatments. All semiochemicals were purchased from Synergy Semiochemicals Corp. Successful challenge to insecticide treatments by this method depends on the attraction of female SPB to the trap, which then fall into the collecting container and attack the bolt that is lying in the bottom ad libitum. Female Dendroctonus bark beetles initiate attacks and are primarily responsible for creating nuptual chambers and galleries; their activity is necessary for determination of treatment success. Although still male-biased, the lure combination with endo-brevicomin is believed to attract the same sex ratio as the lure without, at least under the conditions evaluated to date (Sullivan et al. 2007).

In New Jersey, bolts were assigned to trap locations using a randomized complete block design with six blocks and five bolts per block (one from each treatment). Clarks Landing was a larger infestation, so four blocks ( $\mathrm{n}=20$ bolts) were installed there with the remaining two ( $\mathrm{n}=10$ bolts) being installed at Harding. Bolts were checked twice daily, which allowed researchers to observe attacks and manipulate blocks when needed to create more beetle pressure. Each time any manipulation was done (e.g., trap locations moved within an infestation), the entire block was treated similarly and treatments were re-randomized. As the experiment progressed, it became clear that bolts were not being attacked 


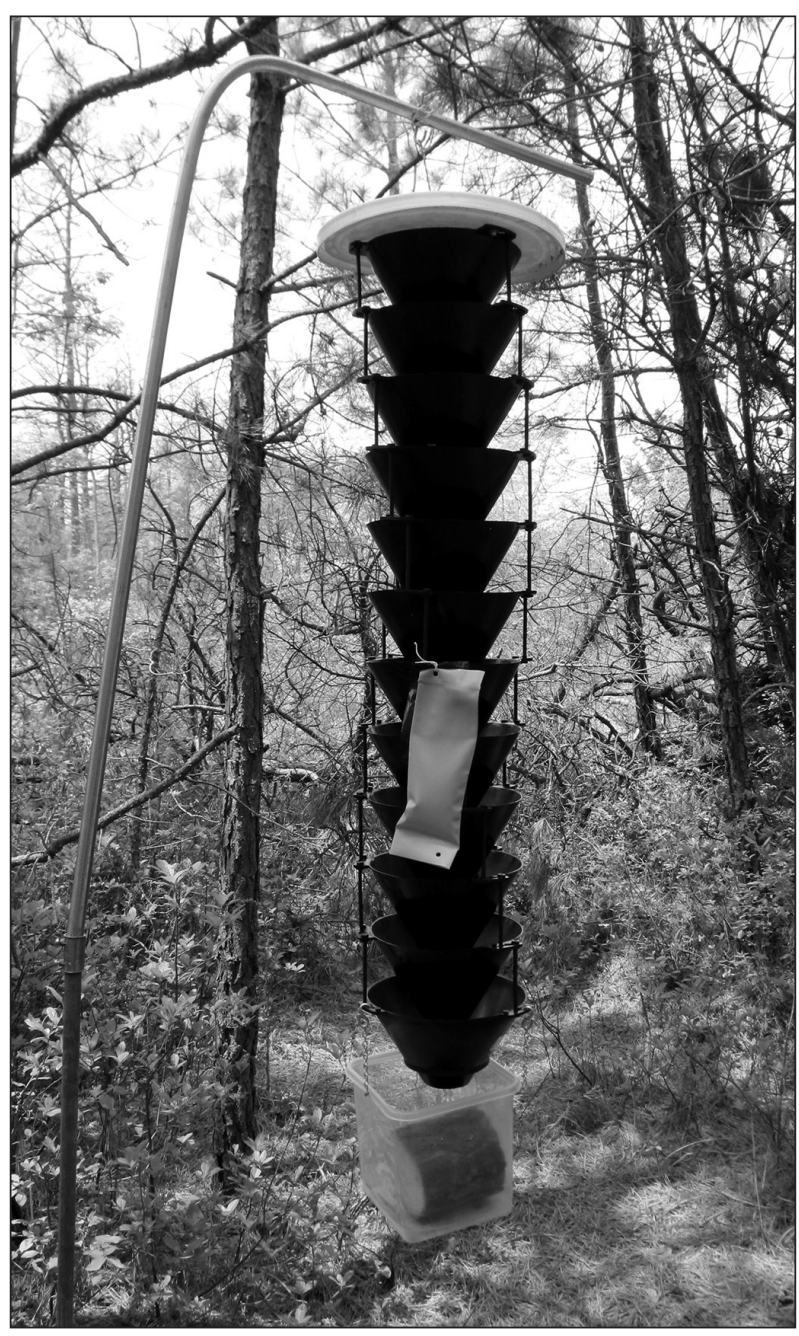

Figure 2. To attract southern pine beetles (SPB) and challenge treatments in the field, bolt sections were placed in a bucket and attached to the bottom of a baited Lindgren multiple funnel trap. Laboratory evaluations were also conducted and provided higher pressures of SPB for treatment evaluations.

as expected. A high concentration of the predaceous clerid beetle (Thanasimus dubius), was apparent in the buckets and appeared to have impacted attacks by eating trapped SPB. To combat this, researchers placed a screen between the bottom funnel and the bucket (Ross and Daterman 1998) during the experiment. Researchers also collected all insects from buckets in selected blocks on two occasions between May 17 and 20 so that sex ratios of SPB could be determined. Again, all manipulations were made while ensuring entire blocks were treated similarly.

A second field evaluation was conducted with SPB in Mississippi (MS) (Homochitto National Forest) June 5-12, 2012. Study trees were cut on
May 25, 2012-72 days posttreatment—and stems stored at $\sim 8^{\circ} \mathrm{C}$ until being bucked for small bolts on June 4, 2012. Methods followed those used in $\mathrm{NJ}$ except for two changes made in response to the poor attack numbers that were observed in NJ. First, endo-brevicomin was removed from the attractant lure because in the past it has produced little impact on trap catches of SPB within infestations in the southeast, and there are many environmental variables that seem to impact catches with this lure (Sullivan et al. 2011). This made researchers unsure of impacts on sex ratio under the conditions of the current experiment. Second, bolts were deployed in MS using a completely randomized design because blocking was not effective at the NJ site; the study authors reverted to a simpler design.

Due to the low pressures realized with SPB in the field portion of this study, three additional field trials were conducted with the small southern pine engraver ( $I$. avulsus) to provide additional data on treatment impacts. All three trials were conducted in central Louisiana (Stuart Seed Orchard, Catahoula Ranger District, Kisatchie National Forest). Ips avulsus is not a major pest but was targeted because it can cause pine mortality and provides a predictably high level of challenge to study bolts deployed in central Louisiana (pers. obs.). Traps with bolts were baited using an attractant combination for this species: racemic ipsdienol and lanierone (Strom et al. 2003). Trials used bolts from the same group of treated trees as the SPB portions of the study (Table 1). The first Ips trial was conducted May 14-21, 2012, and included 10 bolts, one each from two donor trees per treatment. Trees were shared with the SPB trial in New Jersey and were cut on May 11 (58 days post treatment). The second trial was conducted June 5-12, 2012, and also included 10 bolts, two bolts each from a single tree per treatment. Trees were shared with the Homochitto SPB evaluation. The third trial was conducted July 18-25, and included 10 bolts, one each from two trees per treatment. Trees were cut on July 15 (123 days post treatment). Bolt evaluation procedures followed Strom and Roton (2011) and used subsampling of phloem with a round punch $(1.3 \mathrm{~cm}$ diameter; C.S. Osborne and Co., Harrison, New Jersey, U.S.) to assess both the lower threshold for verifying chal- 
lenge by beetles (at least $50 \%$ of subsamples with activity) and the threshold for treatment effectiveness (no more than 20\% of subsamples positive for I $s$ activity to indicate an effective treatment).

\section{Small-Bolt Laboratory Evaluation of Tree Protection Treatments}

Laboratory evaluations of treatments were conducted with SPB and employed methods previously developed for testing tree protection treatments with this species (Strom and Roton 2009). Southern pine beetles emerged into refrigerated containers from infested pitch pine bolts taken from the Harding site. Within 48 hours of emergence, SPB were separated into groups of 75 and released into plastic and screen containers $(\sim 6,900$ $\mathrm{cm}^{3}$; Pioneer Plastics, Inc., Dixon, Kentucky, U.S.) with small bolts. Beetles were allowed to attack ad libitum for 48 hours, at which time the containers with beetles were placed into refrigerators to suspend their activity until bolt dissections.

Three experimental trials were conducted in the laboratory (Table 1). The first two utilized NJ beetles and bolts from the same trees as the field trial in MS. The third laboratory trial used SPB from MS, collected and handled in the same way as the NJ beetles. New Jersey SPB were confined with bolts on May 25, 2012 (72 days posttreatment) and May 31, 2012 (78 days posttreatment). For both trials with NJ beetles, the trees were the same and were cut on May 25, 2012, one tree per treatment. The combination of treatments (five) and replicates (two bolts) provided 10 bolts in each trial, four replicate bolts per treatment over the two trials. Beetles from Mississippi were used in the third trial, which began on July 16, 2012 (124 days post treatment), with study trees being cut on July 15, 2012. In this trial, two trees per treatment were used, each donating two bolts to the test. This resulted in 20 bolts (five treatments, two trees per treatment, two bolts per tree, providing four replicate small-bolts per treatment).

\section{Evaluation of Bolts}

Small bolts were evaluated similarly whether exposure to SPB took place in the field or in the lab; however, increased replication in the lab allowed more extensive evaluation of treatments. Both field- and lab-exposed bolts were dissected in the laboratory by first removing SPB from the outer bark, where they are often found in crevices, and counting them along with those found elsewhere in the container. Bolts were then dissected by paring away the outer bark, counting the number of attacks (nuptial chambers and galleries), and measuring the total length of adult gallery constructed in the bolt during the exposure period. Parameters for discerning successful versus unsuccessful treatments outlined elsewhere (Strom and Roton 2009; Strom and Roton 2011) were adopted with slight revision for this study. Briefly, the interest was to determine treatment efficacy (i.e., the ability of a treatment to achieve a management objective defined a priori). In this case, the desire was to determine a probability that a treatment will protect trees from beetle-caused mortality under verifiable pressure (Shea et al. 1984). This cannot be done directly using the methods in this study because tree mortality was not an observation available to researchers. However, treatments were evaluated against a predetermined level of protection, and where sample sizes were sufficient, treatments were also compared. Strom and Roton $(2009 ; 2011)$ suggest that successful protective treatments be identified by one or more of the following criteria: a 95\% confidence interval (CI) that includes zero for the average number of attacks for each treatment; fewer than two attacks per bolt; or, for I. avulsus, $\leq 20 \%$ of subsamples positive for beetle activity. For this study researchers revised the CI approach to employ a one-way interval [lower boundary (LB) only] to increase the statistical power for eliminating ineffective treatments. This change did not affect the results of this study, but it is believed to be a better approach. For all of these methods it is suggested that a minimum of four to five replicate bolts be used to establish each mean and that a predetermined level of beetle activity be observed in control bolts to accept a test as valid (Table 1). For SPB, $\geq 5$ attacks per control bolt was proposed as a minimum threshold for experimental validity, and for I. avulsus, $\geq 50 \%$ of subsamples being positive for activity (Strom and Roton 2009; Strom and Roton 2011). When beetle pressure does not result in these criteria being met on control bolts, the test is not considered valid for treatment inferences.

Exposure of beetles to systemic treatments occurs at a different stage in the host selection 
process than it does with bole sprays; a consideration for developing evaluation criteria. Attacking beetles must penetrate the outer bark before they are exposed to a systemic insecticide in the phloem, whereas with bole sprays, beetles may be killed on the outer bole prior to reaching the inner bark. Treated tissues must be contacted, and usually consumed, for the most toxic effect to be realized from systemics, so assessing the number of attacks may provide an incomplete determination of treatment effects. Attack number has not been reduced by even those systemics with the greatest impact against bark beetles (Grosman et al. 2009; Strom et al. unpublished data), and under certain conditions one would expect the number or density of attacks to increase due to shorter beetle galleries and the consequent increase in acceptable phloem tissue available to subsequent attackers. Strom and Roton (2009) did not evaluate systemic treatments and did not address this difference in treatment activity when proposing guidelines. For systemic treatments, attack number may retain importance, but utilization of phloem is also important for assessing toxicity. To address this, researchers of the current study evaluated attack number and the gallery length per attack (GLA) and compared treatments using analysis of variance (ANOVA) when sample sizes allowed. Transformation by natural $\log$ or square root was used when data histograms and residual plots showed improvement toward normality and homogeneous variances; the better of the two transformations for meeting these criteria was selected in each case. This analysis provides a first-step toward producing thresholds for effectiveness; however, the relatively late exposure of adult beetles during the attack process and the relatively slow effects of some systemic AIs may conspire to reduce their utility under high bark beetle pressures (see Discussion). Readers are cautioned about interpreting ANOVA results as being predictive of resource protection or field (in situ) efficacy.

\section{Determination of Imidacloprid Residues}

Imidacloprid residue concentrations in phloem were assessed with polyclonal enzyme-linked immunosorbent assay (ELISA) kits (EnviroLogix ${ }^{\mathrm{Tn}}$,
Portland, Maine, U.S.) for untreated and imidacloprid-treated study trees (Fisher et al. 2009). Upon felling, a representative bolt from each tree was stripped of its phloem, which was then collected and kept frozen $\left(-19^{\circ} \mathrm{C}\right)$ until preparation of samples for residue determinations. Samples were oven dried at $38^{\circ} \mathrm{C}$ for at least 48 hours, followed by grinding in a Wiley mill (mesh size 20). A $0.5 \mathrm{~g}$ portion of each ground sample was extracted in $10 \mathrm{ml}$ of chromatography grade methanol (Burdick and Jackson, Muskegon, Michigan, U.S.) with overnight horizontal agitation. Following removal from the agitator, samples were placed upright, sediment was allowed to settle and $1.5 \mathrm{ml}$ from each sample transferred to a $12 \mathrm{~mm} \times$ $32 \mathrm{~mm}$ autosampler vial with a Teflon-lined screw cap (SUN SRI, Rockwood, Tennessee, U.S.). Samples were refrigerated $\left(4^{\circ} \mathrm{C}\right)$ until determinations of residue concentrations were made. For ELISA, all kit instructions were followed. Duplicate wells were used for each sample and their mean recorded. The dynamic range of the Envirologix imidacloprid kit is 0.2 to $6.0 \mathrm{ng} / \mathrm{ml}$, so serial dilutions were made from samples, as needed, until a result within this range was achieved. A Biotek ELx808 plate reader (Biotek, Inc., Winooski, Vermont, U.S.) was used to measure absorbance at $450 \mathrm{~nm}$, and results calculated using 4-parameter curve fitting software (Biotek Gen5, Biotek, Inc.). Both matrix-only blanks and imidacloprid spikes (6 $\mu \mathrm{g} / \mathrm{g}$ dry weight) were included with each plate to provide an estimate of matrix interferences and to ensure kit performance. The mean value generated from duplicate samples was used for analysis.

\section{RESULTS}

Small bolts from different treatments did not differ in size. The average bolt diameter in SPB field trials was (mean \pm 1 SEM) $11.2 \pm 0.3 \mathrm{~cm}$, average length was $10.9 \pm 0.07$ and bark surface area averaged $384.8 \pm 9.4 \mathrm{~cm}^{2}$. In lab trials, these values were $10.9 \pm 0.2 \mathrm{~cm}$ for diameter, $11.1 \pm 0.04 \mathrm{~cm}$ for length, and $379.2+7.2 \mathrm{~cm}^{2}$ for bark surface area. Two-way analysis of variance was used to compare bolt surface area by block and treatment and resulted in no significant differences (field: $\mathrm{F}_{4,13}=$ 0.61, $P=0.66$; lab: $\mathrm{F}_{4,33}=0.81, P=0.53$ ). Because bolts did not differ in size by treatment, researchers did not correct for bolt size in evaluations. 


\section{Small-Bolt Field Evaluation of Tree Protection Treatments}

Small bolts that were challenged by SPB in the field received lower beetle pressure (fewer attacks) than desired. In New Jersey, traps were baited to begin the exposure period on May 15, 2012, 62 days after trees were treated in central Louisiana. Treated bolts were deployed in a randomized complete block design at two sites. None of the four blocks at Clarks Landing received a sufficient number of control bolt attacks to indicate a valid test (Strom and Roton 2009), so they were excluded from analyses. At Clarks Landing, the mean number of control bolt attacks sitewide (across blocks) was $0.5 \pm 0.29$ (mean \pm 1 SEM, $\mathrm{n}=4$ ). At the Harding site, bolts received more pressure from $\mathrm{SPB}$, and the number of attacks on control bolts $(6.5 \pm 1.5$, $\mathrm{n}=2$ ) exceeded the minimum attack threshold. This was also true in Mississippi $(5.5 \pm 1.5, \mathrm{n}=2)$. Bolts treated with either Astro or Onyx sustained no attacks and had no gallery construction at the Harding or Mississippi sites. In contrast, systemic imidacloprid treatments were considered ineffective as they received $>2$ attacks per bolt on average. At the Harding, NJ site, Xytect bolts (mean $=9.5$ $\pm 4.5, \mathrm{n}=2$ ) and Dominion bolts (mean $=3.0$ $\pm 1.0, \mathrm{n}=2$ ) were both above the threshold for effectiveness, and the same was true for the Mississippi site (Xytect mean $=20.5 \pm 7.5$; Dominion mean $=4.5 \pm 2.5$ ). Plans for additional replicates were abandoned due to the low number of attacks received on bolts in the field traps. Due to the low number of valid replicates achieved at the NJ and MS sites, researchers did not pursue the CI evaluation criterion or comparisons by ANOVA.

Collections of insects from buckets in New Jersey revealed that the sex ratio of captured, intact SPB was strongly male biased, far more than expected. In the 10 replicates collected over the course of four days (50 buckets), total captures were: 233 female SPB; 4,334 male SPB; 5,153 clerids; 43 Temnochila virescens; and $42 \mathrm{D}$. terebrans. The number of female SPB is critical for bolt attack and therefore treatment challenge, and ranged from 0 to 91 , with a mean of 4.7. The mean sex ratio (male:female) was 18.6:1 (94.6\% male). The low number of female SPB and the high number of clerids are likely to blame for the lack of bolt attacks observed in New Jersey; more data need to be gathered on lure effects on SPB sex ratio over a range of conditions so that female numbers can be more effectively manipulated.

Field assessments using bolts from the treated trees were conducted in Louisiana with I. avulsus in three trials (Table 1; Figure 3). The first trial began on May 14, 2012 (58 days posttreatment), with bolts that were cut on May 11. There were two bolts per treatment. As expected, bolts received heavy attack pressures from I. avulsus with $100 \%$ of untreated control samples having beetle activity. Neither imidacloprid product was effective at reducing bolt use by $I$. avulsus: Xytect bolts had 25/30 (83.3\%) samples positive and Dominion had $35 / 36(97.2 \%)$. Onyx was also ineffective $(17 / 33,51.5 \%)$, leaving Astro (0/36) as the only treatment considered effective in this trial. The second trial began June 5, 2012 (83 days posttreatment), and resulted in a similar pattern. Control bolts showed a heavy challenge (38/39 samples positive, 97.4\%), and Astro was the only effective treatment ( $0 / 30$ samples positive). Dominion $(30 / 33,90.9 \%)$, Xytect $(37 / 42,88.1 \%)$, and Onyx $(27 / 42,64.3 \%)$ were ineffective. The third and final evaluation with $I$. avulsus began on July 18 (126 days posttreatment). In this trial, control bolts showed a valid test (36/36 samples positive) and none of the treatments were effective. In addition, their relative effectiveness ranking had changed: Dominion were the poorest performer (30/33, 90.9\%), followed by Onyx (24/36, 66.7\%), Astro (19/33, 57.6\%), and Xytect (14/27, 51.9\%).

\section{Small-Bolt Laboratory Evaluation of Tree Protection Treatments}

In the three laboratory trials, treatments received a more vigorous challenge from SPB than in the field trials (Figure 4). Two experimental trials were conducted with NJ beetles and one with MS beetles (Table 1). Each laboratory trial resulted in a valid test, with control bolts averaging $28.6+$ 1.5 attacks across the three trials. As in the field portion of the study, only the bole sprays, Onyx and Astro, effectively reduced or eliminated SPB attacks. In two trials, attacks and gallery lengths were zero, while in the third, each of these two treatments had a single bolt that received one attack. The imidacloprid systemic products were ineffective by either of the criteria, each averag- 
ing $>2$ attacks (Figure 4A) and with lower boundaries of their $95 \%$ CIs that did not include zero. Eight replicate bolts were available from which treatment means and CIs were determined. Astro $($ mean $=0.016)$ and Onyx $($ mean $=0.016)$ were again excluded from the determination of CIs because the lack of variation in attack numbers did not allow for them to be generated. None of the other treatment means included zero in their 95\% CI (back-transformed from square root transformed data): control (mean $=28.5, \mathrm{LB}=$ 25.6), Dominion (mean $=25.6, \mathrm{LB}=22.8$ ), or Xytect (mean $=26.7, \mathrm{LB}=23.1)$, indicating their failure to achieve efficacy based on this criterion.

Unlike the field portion of this study, researchers had sufficient replicates and beetle pressure to evaluate treatment impacts using additional criteria to gain information about the systemic treatments. Using two-way ANOVA (trial and treatment plus trial*treatment interaction) on square root transformed attacks, laboratory trial*treatment interaction was NS (F8, $25=1.58, P=0.18)$, suggesting that treatment

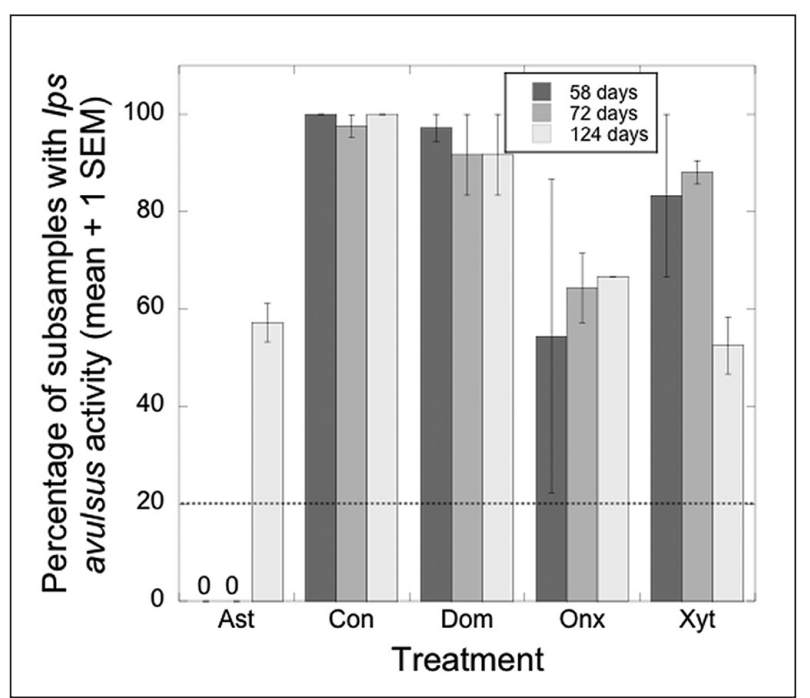

Figure 3. Average percentage of subsamples per small bolt that was positive for Ips avulsus activity (beetle or gallery) in field bioassays in central Louisiana. Weeklong trials began at 58,72 , and 124 days posttreatment, each indicated by a different bar shade. For treatments to be considered sufficiently challenged by $I$. avulsus, control bolts (Con) must have $50 \%$ of subsamples with activity; all three trials met this criterion. Effective treatments are indicated by fewer than $20 \%$ of subsamples having activity (hashed horizontal line). Astro (Ast) at 58 and 72 days posttreatment (both 0 attacks) was the only effective treatment by this criterion. Sample size was two bolts per treatment per trial. effects were similar for New Jersey and Mississippi beetles in this environment and allowing the study authors to combine data across trials. Comparing treatments using Tukey's HSD with pooled error $\left(\mathrm{F}_{4,33}=369.0, P<0.0001\right)$ showed that the two bole sprays resulted in significantly fewer attacks compared to controls and imida-

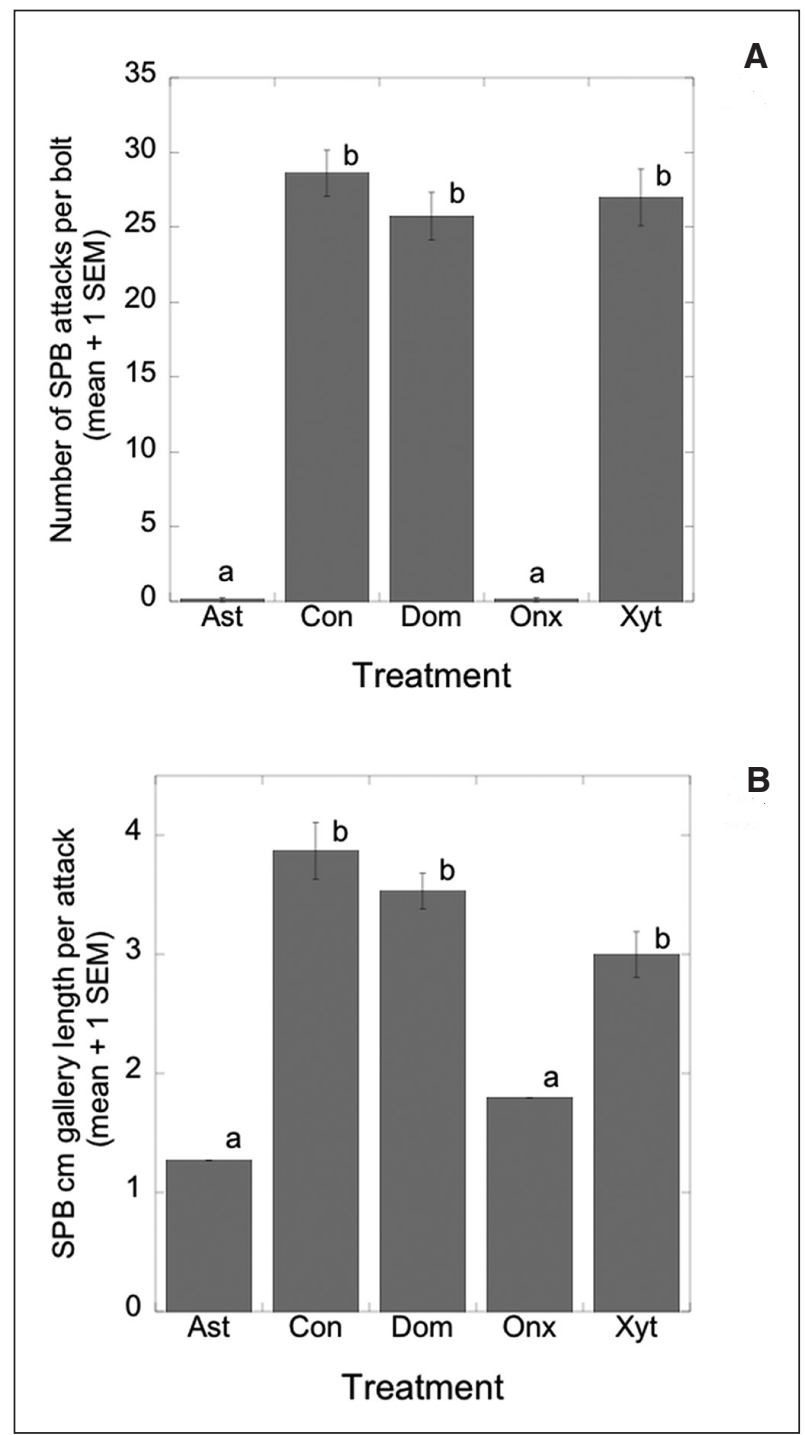

Figure 4. Average number of attacks (a) and average $\mathrm{cm}$ gallery length produced per attack (GLA) (b) by the southern pine beetle (SPB) in laboratory small-bolt assays. Each bar depicts the mean \pm 1 SEM of $n=8$ bolts. Treatments were: Ast $=$ Astro, Con $=$ control, Dom $=$ Dominion, Onx $=$ Onyx, and $\mathrm{Xyt}=$ Xytect. Bars with different letters represent means that were significantly different (Tukey's HSD). Bolts were exposed to about 75 unsexed adult SPB in bioassay arenas for 48 hours between 72 and 124 days post-application of treatments to trees. Please note differences in the ordinate among plots. 
cloprid, but the imidacloprid treatments produced no effect relative to controls (Figure 4A).

As mentioned, the method of exposure and mode of activity of systemics against bark beetles suggest that gallery length measures are important for evaluating their effects. Two-way ANOVA (trial and treatment plus trial ${ }^{\star}$ treatment interaction) on ln transformed GLA resulted in a NS effect for laboratory trial ${ }^{*}$ treatment interaction $\left(\mathrm{F}_{8,25}=0.95, P=0.49\right)$. Using pooled error, the treatment effect was highly significant $\left(\mathrm{F}_{4,33}=658.5, P<0.0001\right.$; Figure 4B). Bole sprays again performed better than other treatments, allowing for significantly shorter galleries per attack (Tukey's HSD with pooled error; Figure 4B); however, their effectiveness at eliminating attacks resulted in the availability of only one bolt each for evaluating this response.

\section{Determination of Imidacloprid Residues}

Because the experimental time frame (trees were cut between 58-124 days after treatment) and tree-level replication (one to two trees per exposure period) were limited, residue results were combined across sites and times for analysis. Untreated control samples (matrix only) averaged $0.19 \pm 0.06 \mu \mathrm{g} / \mathrm{g}$ dry weight $(\mathrm{n}=9)$ and were significantly lower than either imidacloprid treatment. The two imidacloprid treatments did not differ in concentration of residues in the phloem: Dominion samples averaged $0.74 \pm 0.16$ $(\mathrm{n}=9)$ and Xytect samples $1.31 \pm 0.26(\mathrm{n}=9)$.

\section{DISCUSSION}

Southern pine beetle is not foreign to New Jersey but outbreaks are infrequent. New Jersey is included in early range maps and the species was previously observed in the United States in southern Pennsylvania, West Virginia, and Maryland (Hopkins 1909; Hopkins 1921). Prior to 2002, the last outbreak in New Jersey appears to have been in 1939 (The Philadelphia Inquirer 2011), but researchers have not located references that describe it. Although native, SPB are invasive and damaging when populations increase to high levels. Outbreaks are unpredictable, costly, and highly disruptive to forest management. High-value trees in urban forests, recreational areas, and homeplaces suffer mortality with few options for their protection. Cutting, to provide more optimal tree spacing, remove brood trees, or provide buffer zones, is often difficult or unfeasible in environments with high-value trees, leaving insecticides as the only known effective option for protecting selected trees. Research on the identification and deployment of disruptant semiochemicals is ongoing, but efficacious alternatives have yet to be identified for SPB (Strom and Clarke 2011).

About $62 \%$ of forestlands in New Jersey are owned by families, and $73 \%$ of that group own between 0.4 and 4.9 ha (Crocker et al. 2008). Among these owners, aesthetics and nonindustrial uses are central to their objectives (Crocker et al. 2008), suggesting trees will be managed as high-value entities and their protection from identifiable hazards, like SPB, will be considered. Insecticide treatments can be expensive and are generally ineffective for goals other than protection of individual trees or resources. That is, they are not effective for population suppression, although infested boles may be cut and sprayed to reduce or eliminate the emergence of viable SPB brood (Swain and Remion 1983). Although there exist limited options for protecting pines from SPB, registered insecticidal products include bole sprays and systemics. In this and other studies with bark beetles, systemic products have underperformed bole sprays during the year of application (DeGomez et al. 2006; Grosman and Upton 2006). Against other forest insects, soil drenches in particular have shown inconsistent or delayed effects (Xu et al. 2008; Doccola et al. 2012). This is not surprising because soil drenches are subject to additional environmental influences through the soil and over time, but it is an important consideration for tree protection treatments against bark beetles. Stem-injected products are less susceptible to those influences but usually require some level of tree injury for application and may introduce other heterogeneities via the spatial pattern of injection points. They also, however, may provide multiple-year effects and have more impact against bark beetles (Grosman et al. 2002; Grosman et al. 2010) along with a wider range of available AIs; the utility of stem-injected products against bark beetles continues to be evaluated (e.g., Grosman et al. 2010; Strom et al. unpublished).

Regardless of application method, systemic AIs now available, including imidacloprid, must be ingested by the attacking beetles to be most effec- 
tive. Contact toxicity has been observed but LC50s are about 10x lower for ingested compared to contact toxicity with the Asian longhorned beetle (ALB) (Anoplophora glabripennis) (Wang et al. 2005). Even with ingestion, mortality from imidacloprid can occur slowly in adult beetles. For example, with ALB feeding on Norway maple (Acer platanoides) a $1.3 \mathrm{ppm}$ residue concentration required 21 days to kill $50 \%$ of the population (Ugine et al. 2012). In addition, even with stem injection, only $5.2 \%$ of treated trees eliminated egg laying (Ugine et al. 2012). Sub-lethal effects may help to increase effectiveness but they are as yet undetermined, and with bark beetles they are probably less useful because beetles are already attacking, producing gallery and attractants, and exposing the tree to phoretic organisms. Researchers do not know the tissue residue concentrations of imidacloprid required to impact bark beetles, but tree protection from these pests requires faster action resulting in less adult activity than indicated for ALB in the Ugine et al. (2012) study. Although feeding by adult ALB may be a target for insecticides, bole protection requires larval poisoning. A similar situation exists with the emerald ash borer (EAB) (Agrilus planipennis); however, with bark beetles, adult activity kills the host tree so they must be impacted directly and quickly by phloem residues to provide adequate tree protection.

The mode of activity of systemic insecticides creates at least three problems for tree protection against bark beetles. Current systemic products do not reduce the number of attacks, they do not impact associated organisms (e.g., fungi), and attacking beetles are still able to make galleries, even if abbreviated. Thus, the magnitude of the feral population of beetles becomes integral to treatment effectiveness because a high number of attacks is still likely to kill a host tree almost regardless of beetle success. That is, attacking beetles construct galleries and produce frass, so even if gallery length is significantly reduced, an ample pool of feral beetles may still be sufficient to cause treatment failure through a higher attack density. On the other hand, quantifying ambient beetle populations is notoriously difficult, as is estimating the number of beetles available to attack a particular tree in time and space. This can lead to a treatment appearing to be effective, particularly over short beetle exposure periods, so long as it is marginally more effective than doing nothing. Successful mass attack requires synchronous events, which in turn require an ample pool of attackers during a limited moment in time (probably weeks or less, but this can happen in more than one episode). In addition, the impact of organisms like fungi, that are phoretic on beetles and inoculated during the attack process, is uncertain in the unnatural within-tree environment created by an effective systemic; research into these factors is only beginning.

The study authors do not know the ingested dosage of imidacloprid, or residue concentrations, that are required to impact SPB. However, residue values in this study were low for successful tree protection, although similar to those observed in other types of tissues researchers and others have examined (Xu et al. 2008; Fischer et al. 2009; Ugine et al. 2012). In results from published laboratory studies, SPB kept at $28^{\circ} \mathrm{C}$ averaged $2.55 \mathrm{~cm}$ of gallery before the first egg niche (Clarke et al. 1979). It is widely believed that under natural conditions, oviposition by SPB is indicative of a host that will succumb to attack. Thus, one method for developing a threshold value to assess the potential utility of a systemic insecticide is to select a portion of the gallery length as a target reduction that must be achieved to indicate treatment success. Shea et al. (1984) employ a target of $90 \%$ (80\% with the CI) protection (tree survival) as a basis for efficacy with standing trees, and Strom and Roton $(2009 ; 2011)$ base their preliminary suggestions for screening effectiveness with host bolts on this approach. They suggest, as a starting point for assessing treatments, the number of attacks must be reduced by $80 \%$ relative to controls for a treatment to be considered effective. For gallery length, $20 \%$ of the overall control average for field-generated GLA in the present study would provide a gallery length value of about $1.3 \mathrm{~cm}$, or half of the gallery length that is typical before the first egg. If adopted in this study, this criterion would agree with the other criteria and result in neither imidacloprid product in this study being considered successful.

Another possible approach to predicting the utility of systemics is to use an experimentally determined toxicity of the AI for the target insect and estimate the tissue consumption needed for this amount to be ingested. This level of tissue consumption can be considered as likely to occur because toxic levels 
would not be ingested until it is reached; the resulting plant injury can then be evaluated for its consequences on achieving management goals. For SPB, the toxicity of imidacloprid is unknown, precluding a direct estimate. However, an example of the approach can be generated by assuming imidacloprid toxicity is similar between $\mathrm{SPB}$ and $\mathrm{EAB}$, which has an estimated oral LD50 of $7.1 \mathrm{ng}$ /adult beetle (Cregg et al. 2005). With respect to SPB this is probably conservative because EAB is considered to be relatively susceptible to imidacloprid, while imidacloprid treatments have been ineffective against SPB and other bark beetles (DeGomez et al. 2006; Grosman and Upton 2006). Windell and Kautz (2007) report the average mass of adult $\mathrm{EAB}$ to be $25.6 \mathrm{mg}$ for males and $43.5 \mathrm{mg}$ for females. Adult SPB mass also varies by sex, but a mean of about $1 \mathrm{mg}$ is reasonable (Wagner et al. 1981; Ayres et al. 2000), so at the same susceptibility level an estimated LD50 would be about 30 times lower, or 0.24 ng imidacloprid, per adult beetle. At an average imidacloprid tissue concentration of $1 \mu \mathrm{g} / \mathrm{g}$ phloem dry weight, as observed in the current study, a consumption of 240 $\mu \mathrm{g}$ dry weight of phloem tissue would be required to reach the projected LD50 level. The specific mass of loblolly pine phloem has been estimated as $29.8 \mathrm{mg} / \mathrm{cm}^{2}$ dry weight (Ayres et al. 2000). Southern pine beetles are about $1.25 \mathrm{~mm}$ wide (Wagner et al. 1981) and are assumed cylindrical. Gallery width should be slightly larger but similar. A 2.54 $\mathrm{cm}$ long gallery should encompass the movement of about $31.2 \mathrm{~mm}^{2}$ phloem tissue, or $0.312 \mathrm{~cm}^{2}$, leading to a total phloem displacement of $9.3 \mathrm{mg}$. This amount of phloem would be estimated to contain $0.0093 \mu$ g imidacloprid or $9.3 \mathrm{ng}$ or about $39 \mathrm{x}$ the necessary tissue for the estimated LD50. Although contact toxicity may affect the overall toxicity of the treatment (e.g., Wang et al. 2005), the observed gallery lengths suggest the LD50 assumptions estimated from $\mathrm{EAB}$ are indeed inaccurate and that SPB is less susceptible to imidacloprid than is $\mathrm{EAB}$, perhaps being closer to $10 \mathrm{ng}$ /adult beetle.

Additional experiments, conducted in situ, are necessary to clarify the efficacy of bole spray treatments against SPB in New Jersey. Field studies are expensive and have the primary difficulty of requiring that a threshold of untreated trees be killed before inference can be made regarding treatment efficacy (Shea et al. 1984). Also, established methods for in situ studies are more difficult to employ successfully with SPB than with related western species (for which they were initially developed) because of the nature of SPB's spot infestations. The level of aggregation in SPB is very high, causing heterogeneity in beetle recruitment across long transects, and alternatively, with the management of "spillover" attacks that occur on trees nearby to study trees. This is particularly difficult in areas where spillover trees cannot be quickly and efficiently cut or harvested. However, if determination of a single, best treatment for tree survival is considered important, including factors like treatment durability and the probability of tree mortality under various field conditions, then Astro and Onyx should be compared on standing trees in a well-replicated experiment under sufficiently high beetle pressures.

Researchers of the current work interpret the results of this study as support for the effectiveness of permethrin and bifenthrin products applied as bole sprays to uninfested pines for the prevention of attack by SPB. In addition, SPB from New Jersey responded similarly to those from Mississippi to the treated bolts, suggesting that extrapolation from previous studies with SPB in the southeastern U.S. may be useful for predictions with New Jersey SPB and their response to insecticide treatments. However, differing environmental conditions between New Jersey and those areas more often infested with SPB, especially winter duration and temperatures, dictate that the durability or persistence of bole sprays be studied in New Jersey if this knowledge is considered sufficiently important. To start, the study authors suggest that one season of protection is likely from either bole spray product tested here when properly applied. Imidacloprid products, on the other hand, did not reduce SPB attack number or gallery length per attack. Thus, little or no supporting evidence were seen for the application of either imidacloprid product against SPB. When combined with the ineffective results generated in past studies (Grosman and Upton 2006), researchers would not recommend products based upon this AI for prophylactic treatment of trees for management of SPB. 
Acknowledgments. For technical assistance we thank B. Parpart, J. Parpart, and S. Walters (USDA Forest Service, SRS, Pineville, LA), and field crews from the New Jersey Forest Service, without whom the study could not have been conducted. We thank J. Fischer (USDA Forest Service, SRS, Auburn, Alabama, U.S.) for residue analysis, G. Gladders (DE Department of Agriculture, Forest Service), D. Johnson, J. Klischies and D. Finley (N) Department of Environmental Protection, Division of Parks and Forestry, Forest Service) were instrumental in study design and implementation, and M. Ayres (Dartmouth College) for helpful discussions, particularly regarding phloem use by bark beetles. Cavell Brownie improved the manuscript immensely through her review and insightful advice on statistical evaluations. Funding for this study was provided by the New Jersey State Forestry Service, Trenton, NJ, USDA Forest Service, R8 Forest Health Protection, Pineville, LA and USDAFS, Southern Research Station, Pineville, LA. Any use of trade, product, or firm names is for descriptive purposes only and does not imply endorsement by the United States Government.

\section{LITERATURE CITED}

Ayres, M.P., R.T. Wilkens, J.J. Ruel, M.J. Lombardero, and E. Vallery. 2000. Nitrogen budgets of phloem-feeding bark beetles with and without symbiotic fungi. Ecology 81:2198-2210.

Berisford, C.W., U.E. Brady, G.E. Fitzpatrick, C.K. Franklin, F.L. Hastings, A.S. Jones, and J.H. Lashomb et al. 1981. Efficacy Studies: Prevention. pp. 9-12. In: F.L. Hastings and J.E. Coster (Eds.). Field and Laboratory Evaluations of Insecticides for Southern Pine Beetle Control. USDAFS General Technical Report SE-21, Southeastern Forest Experiment Station, Asheville, North Carolina, U.S.

Cameron, R.S. 1987. Southern pine bark beetles in the urban environment. Journal of Arboriculture 13:145-151.

Clarke, A.L., J.W. Webb, and R.T. Franklin. 1979. Fecundity of the southern pine beetle in laboratory pine bolts. Annals of the Entomological Society of America 72:229-231.

Cregg, B.M., D. Mota-Sanchez, D.G. McCullough, T. Poland, and R. Hollingworth. 2005. Distribution and metabolism of 14C imidacloprid in Fraxinus spp. and effects of imidacloprid on adults of the emerald ash borer. Abstract. pp. 46-48. In: V. Mastro and R. Reardon (compilers). Emerald Ash Borer. Research and Technology Development Meeting, Romulus, Michigan, Oct 5-6, 2004. US Department of Agriculture Forest Service, Forest Health Technology Enterprise Team publication FHTET-2004-15, Morgantown, WV. 83 p.

Crocker, S.J. 2012. New Jersey's forest resources, 2011. Res. Note NRS-156. Newtown Square, PA: U.S. Department of Agriculture, Forest Service, Northern Research Station. 4 p.

Crocker, S.J., M.D. Nelson, C.J. Barnett, G.J. Brand, B.J. Butler, G.M. Domke, and M.H. Hansen et al. 2008. New Jersey's Forests. Resour. Bull. NRS-59. Newtown Square, PA: U.S. Department of Agriculture, Forest Service, Northern Research Station. 52 pp.

DeGomez, T.E., C.J. Hayes, J.A. Anhold, J.D. McMillin, K.M. Clancy, and P.P. Bosu. 2006. Evaluation of insecticides for protecting southwestern ponderosa pines from attack by engraver beetles (Coleoptera: Curculionidae: Scolytinae). Journal of Economic Entomology 99:393-400.

Doccola, J.J., W. Hascher, J.J. Aiken, and P.M. Wild. 2012. Treatment strategies using imidacloprid in hemlock woolly adelgid (Adelges tsugae Annand) infested eastern hemlock (Tsuga canadensis Carrière) trees. Arboriculture \& Urban Forestry 38:41-49.
Ferguson, T.L., M. Buccowich, and R. Lueckel. 2013. Southern pine beetle in New Jersey: The infestation is expanding. U.S. Department of Agriculture, Forest Service, Northern Area State and Private Forestry Report, 2 p. Accessed 07/08/2013. <www.na.fs. fed.us/ra/specialinitiatives/spb/2013/southern-pine-beetlenew-jersey_130131.pdf>

Fischer, J.B., B.L. Strom, and S.L. Smith. 2009. Evaluation of a commercially available ELISA kit for quantifying imidacloprid residues in Erythrina sandwicensis leaves for management of the Erythrina gall wasp, Quadrastichus erythrinae Kim. Pan Pacific Entomologist 85:99-103.

Grosman, D.M., and W.W. Upton. 2006. Efficacy of systemic insecticides for protection of loblolly pine against southern pine engraver beetles (Coleoptera: Curculionidae: Scolytinae) and wood borers (Coleoptera: Cerambycidae). Journal of Economic Entomology 99:94-101.

Grosman, D.M., C.J. Fettig, C.L. Jorgensen, and A.S. Munson. 2010. Effectiveness of two systemic insecticides for protecting western conifers from mortality due to bark beetle attack. Western Journal of Applied Forestry 25:181-185.

Grosman, D.M., S.R. Clarke, and W.W. Upton. 2009. Efficacy of two systemic insecticides injected into loblolly pine for protection against southern pine bark beetles (Coleoptera: Curculionidae). Journal of Economic Entomology 102:1062-1069.

Grosman, D.M., W.W. Upton, F.A. McCook, and R.F. Billings. 2002. Systemic insecticide injections for control of cone and seed insects in loblolly pine seed orchards-2 year results. Southern Journal of Applied Forestry 26:146-152.

Haverty, M.I., P.J. Shea, and J.M. Wenz. 1996. Metasystox-R, applied in Mauget injectors, ineffective in protecting individual ponderosa pines from western pine beetles. USDA Forest Service, Pacific Southwest Research Station Research Note PSWRN-420, Albany, California, U.S.

Hayes, J.L., J.R. Meeker, J.L. Foltz, and B.L. Strom. 1996. Suppression of bark beetles and protection of pines in the urban environment: A case study. Journal of Arboriculture 22:67-74.

Hopkins, A.D. 1909. Contributions toward a monograph of the scolytid beetles. I. The genus Dendroctonus. U.S. Dep. Agr. Bur. Entomol. Tech. Series 17, part 1, Washington, D.C.

Hopkins, A.D. 1921. The southern pine beetle: a menace to the pine timber of the southern states. U.S. Dept. of Agr. Farmer's Bul. 1188, Washington, D.C.

Klischies, J., and J. Battersby. 2002. Forest health evaluation of southern pine beetle infestations in southern New Jersey (2002 - Year 1). New Jersey Forest Service. Accessed June 8, 2013. $<$ www.nj.gov/dep/parksandforests/forest/njfs_spb.html>

Lindgren, B.S. 1983. A multiple funnel trap for scolytid beetles (Coleoptera). Canadian Entomologist 115:395-410.

New Jersey Government. 2013. Accessed 05/05/2013. <www.nj.gov/ dep/enforcement/pcp/pcp-restricted.htm>

Philadelphia Inquirer, The. April 10, 2011. Accessed 04/08/2013. $<$ www.philly.com/inquirer>

Ross, D.W., and G.E. Daterman. 1998. Pheromone-baited traps for Dendroctonus pseudotsugae (Coleoptera: Scolytidae): Influence of selected release rates and trap designs. Journal of Economic Entomology 91:500-506.

Shea, P.J., M.I. Haverty, and R.C. Hall. 1984. Effectiveness of fenitrothion and permethrin for protecting ponderosa pine trees from attack by the western pine beetle. Journal of the Georgia Entomological Society 19:427-433. 
Strom, B.L., and L.M. Roton. 2009. A small-bolt method for screening tree protectants against bark beetles (Coleoptera: Curculionidae). Journal of Entomological Science 44:297-307.

Strom, B.L., and L.M. Roton. 2011. Effectiveness of cedar oil products for preventing host use by Ips avulsus (Eichhoff) (Coleoptera: Curculionidae) in a modified small-bolt assay. Journal of Entomological Science 46:14-22.

Strom, B.L., and S.R. Clarke. 2011. Use of semiochemicals for southern pine beetle infestation management and resource protection. pp. 381-397. In: R.C. Coulson and K.D. Klepzig (Eds.). Southern Pine Beetle II. USDA Forest Service, So. Res. Sta. Gen. Tech. Rep. SRS-140. Asheville, North Carolina, U.S.

Strom, B.L., S.R. Clarke, and L.M. Roton. 2003. Attraction of Ips avulsus (Eichhoff) to varying enantiomeric composition of ipsdienol in commercially available lures. Journal of Entomological Science 38:137-139.

Sullivan, B.T., M.J. Dalusky, K. Mori, and C. Brownie. 2011. Variable responses by southern pine beetle, Dendroctonus frontalis Zimmermann, to the pheromone component endo-Brevicomin: Influence of enantiomeric composition, release rate, and proximity to infestations. Journal of Chemical Ecology 37:403-411.

Swain, K.M., and M.S. Remion. 1983. Direct control methods for the southern pine beetle. Agriculture Handbook 575. Washington, D.C.: U.S. Department of Agriculture. 15 p.

Ugine, T.A., S. Gardescu, P.A. Lewis, and A.E. Hajek. 2012. Efficacy of imidacloprid, trunk-injected into Acer platanoides, for control of adult Asian longhorned beetles (Coleoptera: Cerambycidae). Journal of Economic Entomology 105:2015-2028.

USDA Forest Service. 2010. Elution Rate Test Results. Accessed 01/25/2013. <www.fs.fed.us/foresthealth/technology/elutionrate>

Wagner, T.L., R.M. Feldman, J.A. Gagne, J.D. Cover, R.N. Coulson, and R.M Schoolfield. 1981. Factors affecting gallery construction, oviposition, and reemergence of Dendroctonus frontalis in the laboratory. Annals of the Entomological Society of America 74:255-273.

Wang, B., R. Gao, V.C. Mastro, and R.C. Reardon. 2005. Toxicity of four systemic neonicotinoids to adults of Anoplophora glabripennis (Coleoptera: Cerambycidae). Journal of Economic Entomology 98:2292-2300.

Windell, K., and J. Kautz. 2007. Determining how much weight emerald ash borer can carry in flight. Forest Health Protection Tech. Rep. 0734-2815. USDA Forest Service, Technology and Development Program, Missoula, Montana, U.S.

Xu, T., C.M. Jacobsen, A.H. Hara, J. Li, and Q.X. Li. 2008. Efficacy of systemic insecticides on the gall wasp Quadrastichus erythrinae in wiliwili trees (Erythrina spp.). Pest Management Science 65:163-169.

Zhong, H., F.L. Hastings, F.P. Hain, and R.A. Werner. 1994. Toxicity of carbaryl toward the southern pine beetle in filter paper, bark, and cut bolt bioassays. Journal of Entomological Science 29:247-253.

\author{
B.L. Strom (corresponding author) \\ Research Entomologist \\ Southern Research Station \\ U.S. Department of Agriculture Forest Service \\ 2500 Shreveport Highway \\ Pineville, Louisiana 71360, U.S.
}

W.K. Oldland

Entomologist

Northeastern Area Forest Health Protection

U.S. Department of Agriculture Forest Service

180 Canfield Street

Morgantown, West Virginia 26505, U.S.

\author{
J.R. Meeker \\ Entomologist \\ Region 8 Forest Health Protection \\ 2500 Shreveport Highway \\ Pineville, Louisiana 71360, U.S. \\ J. Dunn \\ GIS Specialist \\ NJ State Forestry Services \\ P.O. Box 420 \\ Trenton, New Jersey 08625, U.S.
}

U.S. Department of Agriculture Forest Service 
Résumé. Quatre insecticides non-spécifiques d'usage général (Astro ${ }^{\circledR}$, Onyx ${ }^{\star}$, Dominion ${ }^{\star}$ arbres et arbustes, et Xytect $2 \mathrm{~F}^{\oplus}$ ) ont été évalués quant à leur efficacité à prévenir les attaques du dendroctone méridional du pin (SPB) (Dendroctonus frontalis) et du petit graveur méridional du pin (Ips avulsus) en utilisant la méthode dite de la petite cheville (small-bolt method) récemment développée. Les évaluations ont été réalisées entre 62 et 124 jours suivant les traitements. Des dendroctones méridionaux du pin provenant du New Jersey et du Mississippi, aux États-Unis, ont été testés par le biais d'essais sur le terrain et en laboratoire avec la méthode de la petite cheville; la provenance des dendroctones ne semblait pas affecter les résultats. Les pulvérisations sur tronc d'Astro et d'Onyx ont été efficaces pour réduire ou éliminer les attaques du dendroctone méridional du pin, tandis le trempage du sol avec les produits imidaclopride (Dominion et Xytect) était inefficace. Testé sur le petit graveur méridional du pin (Ips avulsus) en Louisiane, aux États-Unis, le traitement sur le tronc avec le produit Astro a réduit les attaques entre 58 et 83 jours suivant la pulvérisation, mais s'est avéré inefficace à 126 jours. Les produits Onyx, Dominion, et Xytect étaient inefficaces contre le petit graveur méridional du pin (Ips avulsus) lors de ces tests. Les résidus d'imidaclopride retracés dans le phloème variaient en moyenne de $0,74(\mu \mathrm{g} / \mathrm{g}$ poids sec du phloème) pour le Dominion et de 1,31 pour le Xytect, des valeurs qui sont similaires à d'autres études, mais faibles pour utilisation à des fins de contrôle. Ces résultats confirment des recherches antérieures à l'effet que l'imidaclopride systémique est inefficace pour protéger les pins contre le scolyte Dendroctonus et que les pulvérisations sur le tronc de bifenthrine ou de perméthrine peuvent être efficaces. Cependant, la perméthrine est le seul ingrédient actif qui se soit montré efficace contre le petit graveur méridional du pin (Ips avulsus) dans la présente étude.

Zusammenfassung. Vier Breitband-Herbizide (Astro ${ }^{\circ}$, Onyx ${ }^{\circ}$, Dominion ${ }^{\star}$ Tree \& Shrub, and Xytect $2 \mathrm{~F}^{\otimes}$ ) wurden bewertet für ihre Effektivität im Einsatz gegen die Attacken des Südlichen Kiefernbohrers (SPB) (Dendroctonus frontalis) und des kleinen Kiefernstechers (Ips avulsus), indem eine vorher entwickelte kleine Bolzen-Methode verwendet wurde. Die Bewertungen wurden zwischen 62 und 124 Tagen nach der Behandlung durchgeführt. Die Südlichen Kiefernbohrer aus New Jersey und Mississippi, U.S., wurden bewertet unter Verwendung einer Mischung aus Feld- und Labormethoden. Die Herkunft der Käfer schien die
Ergebnisse nicht zu beeinflussen. Astro und Onyx Sprays waren effektiv bei der Reduzierung oder der Eliminierung von Attacken durch den SPB, während die Imidacloprid-Produkte zum Giessen (Dominion und Xytect) uneffektiv waren. Bei dem Kiefernstecher aus Lousiana, US., war Astro effektiv bei der Reduzierung von Stammverletzungen nach 58 und 83 Tagen nach der Behandlung, aber es versagte nach 126 Tagen. Onyx, Dominion und Xytect waren bei diesem Test ineffektiv gegen den Ips avulsus. Die Rückstände von Imidacloprid im Phloem lagen durchschnittlich bei $0,74(\mu \mathrm{g} / \mathrm{g}$ Phloem Trockengewicht) für Dominion und 1,.31 for Xytect. Diese Werte sind ähnlich den Werten aus anderen Studien, aber dennoch nicht geeignet für diese Kontrolle. Diese Ergebnisse unterstützen frühere Ergebnisse, dass systemisches Imidacloprid beim Schutz von Kiefern gegen Dendrococcus Borkenkäfer ineffektiv ist und dass Sprays mit Befenthrin oder Permethrin effektiv sein können. Dennoch ist in dieser Studie Permethrin der einzige aktive Wirkstoff gegen Ips avulsus.

Resumen. Se evaluaron cuatro insecticidas de uso general (Astro ${ }^{\circledR}, \mathrm{ONYX}^{\oplus}$, Dominion ${ }^{\star}$ Tree y Xytect $2 \mathrm{~F}^{\star}$ ) para conocer su eficacia en la prevención de ataques del gorgojo descortezador del pino (SPB) (Dendroctonus frontalis) y el pequeño grabador de pino del sur (Ips avulsus) utilizando un método previamente desarrollado. Las evaluaciones fueron realizadas entre 62 y 124 días después del tratamiento. Se evaluaron los escarabajos de pino del sur de New Jersey y Mississippi, Estados Unidos, utilizando una mezcla de pruebas de campo y de laboratorio; el origen del escarabajo no pareció afectar los resultados. Los aerosoles Astro y Onyx fueron eficaces para reducir o eliminar los ataques de SPB, mientras que los productos al suelo imidacloprid (Dominion y Xytect) fueron ineficaces. Con I. avulsus en Louisiana, Estados Unidos, Astro fue eficaz en la reducción a los 58 y 83 días después del tratamiento, pero fracasó en 126 días. Onyx, Dominion, y Xytect fueron ineficaces contra I. avulsus en estas pruebas. Los residuos en el floema de imidacloprid promediaron 0.74 ( $\mathrm{mg} / \mathrm{g}$ de peso seco) para Dominion y 1,31 para Xytect, valores que son similares a otros estudios, pero bajos para efectos de control. Estos resultados apoyan hallazgos previos de que el imidacloprid sistémico no es eficaz para la protección de los pinos contra escarabajos de la corteza Dendroctonus y que los aerosoles con bifentrina o permetrina pueden ser eficaces. Sin embargo, la permetrina fue el único ingrediente activo eficaz contra I. avulsus en el presente estudio. 